\title{
Watercress (Nasturtium officinale): A Potential Source of Nutraceuticals
}

\author{
Yamuna Pandey $^{1 *}$, Siddharth S. Bhatt ${ }^{2}$ and Nadia Debbarma ${ }^{3}$ \\ ${ }^{1}$ College of Horticulture (Thenzawl), Mizoram, Central agricultural university, India \\ ${ }^{2}$ Dev Bhoomi Groups of Institution, Dehradun, Uttarakhand, India \\ ${ }^{3}$ Department of Horticulture, Sikkim University 6th mile Samdur-737102, Sikkim, India \\ *Corresponding author
}

\section{A B S T R A C T}

\section{Key w ords \\ Anti-cancer, \\ Antidiabetic, \\ Antimicrobial \\ activities, Medicinal properties}

\section{Article Info}

Accepted:

24 January 2018

Available Online:

10 February 2018
Watercress (N. officinale) is quick growing perennial herb that is native to Egypt and West Asia, although it is now cultivated in the entire world. Its leaves and arial stem are rich source of proteins, dietary fibre, Vitamins and minerals, other essential nutrients and phytochemicals. Watercress is generally used as traditional medicine for the treatment of diabetic, bronchitis, abdominal pain, asthma, anti- inflammatory, to purify blood, chest pain, stop Haemorrhages, liver, eliminate of excess bile, gallbladder, stimulant, kidneys, lungs, throat expectorant, skin afflictions, facial scars, iron deficiency and digestion. The present review deals with traditional uses, nutritional, phytochemical, antioxidant, antimicrobial, and medicinal potential of watercress. It highlights anti-cancer, antidiabetic, cardioprotective, hepatoprotective and anti-tuberculosis activities of watercress.

\section{Introduction}

N. officinale is a perennial semi-aquatic, high value, wild herb use for culinary purpose by people almost around the world, native to Western Asia, India, Europe and Africa. However, it is now distributed almost globally. It has attractive dark green leaves, a strong flavour and is rich in vitamins. Watercress, which is cultivated for its pungent leaves which are used in cooking especially in soups, garnishes and salads, is one of the most important herbal medicines used for the treatment of some diseases like diabetes in traditional treatment (Shahrokhi et al., 2009), oxidative stress (Yazdanparast et al., 2008), scorch (Abu-Zinadah, 2008) etc. Watercress is a vital source of nutraceuticals and an important detoxifying herb. Palaniswamy et al., (2003) reported that the watercress plant contains a huge amount of vitamins B1, B2, C, pro- vitamin A, folic acid, glucosinolates, iodine, iron, protein, and especially calcium and sulphur compounds which not only influence its characteristic odour, but also adds to its nutritional benefits. The active constituents of watercress extract may strengthen or stimulate the immune response by interacting with various parameters of the immune system. Watercress has been used for so long to cure a number of ailments with claims that it can improve blood circulation 
(Matsushima et al., 2006), to cure renal colic, liver disease (Guarrera et al., 2005) as a mild stimulate, a diuretic, an expectorant and a digestive aid. Being healthy food watercress is very popular and growing widely due to recent remarkable studies and reports of the anticancer compounds it contains.

\section{Traditional uses}

Watercress is one of the most important mountainous medicinal herb mainly used by the rural healers as nutritive, antiinflammatory and antioxidant agent. This plant is a vegetable, consumed raw or cooked in salads, soups and other recipes in European and Turkish cuisine and also used to cure abdominal pain in traditional medicine (Ozen, 2009)and for treatment of diseases like diabetes and bronchitis as reported by (Bahramikia et al., 2009). Kumari et al., (2015) reported that in Baijnath region of Himachal Pradesh traditionally watercress leaves are cooked for making saag, leaves juice applied externally for growth of thick hairs, poultices of leaves help in treating lymphatic swelling. Watercress is used as traditional medicine to purify blood, chest, stop haemorrhages, liver, eliminate of excess bile, gallbladder, stimulant, kidneys, lungs, throat, expectorant, dropsy, skin afflictions, facial scars, iron deficiency and digestion (Graf et al., 2016).

\section{Nutritional constituent}

Watercress is an awesome source of vital nutrients which abundantly contains vitamins and minerals. The presence of different phytochemicals and nutrition make watercress a healthy diet that maintains immunity and good health of the human body. Shahrokhi et al., 2009 mentioned that the watercress is important source of vitamins and a good detoxifying herb. Its high content of vitamin $\mathrm{C}$ and minerals makes it a remedy that is particularly significant for chronic illness. The Vitamins and mineral constituent of watercress according to different sources (FSA, 2002; Pradhan et al., 2015) are shown in Table 1 and 2, respectively.

\section{Phyto chemical constituent}

Hedges and Lister (2005)reported that watercress is well endowed with phytochemicals, including chlorophyll, lutin, $\beta$ - carotene, and the glucosinolates gluconasturtin (which is converted to the isothiocyanate phenethyl isothiocyanate or PEITC), gluconasturtin (which is converted to indole- 3- carbinol or I- 3- C,) a compound similar to an isothiocyanate. Watercress is excellent source of gluconasturtin, with $5.32 \mathrm{~g}$ of gluconasturtin/ $100 \mathrm{~g}$ of defatted seed (Palaniswamy et al., 2003) the precursor to phenenthyl isothiocyanate (PEITC).

$N$. officinele is known to contain eight glucosinolates (Fahey et al., 2001) which are presented in table 3. Which can be subsequently converted to their constituent isothiocyanate. The most abundant isothiocyanate derived from watercress is phenethyl isothiocyanate (PEITC) with watercress being the richest dietary source of this compound (Callaway et al., 2004). Phenethyl isothiocyanate (PEITC) is a phytochemical that inhibits several types of cancers caused by tobacco-specific carcinogens in rat and mice studies as reported by Palaniswamy et al., (2003).

\section{Anti-oxidant activity}

Aries et al., (2013) observed in his studies that the extracts of organic young baby-leaf of watercress contained high antioxidant capacity and this property was largely related with caffeic acid, quercetin-3-O-rutinoside, isorhamnetin, and glucosnasturtiin. Zeb Alam (2015) identified fourteen phenolic 
compounds in the leaves of watercress, where coumaric acid and its derivatives, caftaric acid and quercetin derivatives were present in huge amounts. A total of 20 compounds were identified from roots with coumaric acid and its derivatives, sinapic acid, caftaric acid and quercetin derivatives were the major phenolic compounds present.

Bahramikia and Yazdnaparast (2010) studied the antioxidant efficacy of $N$. officinale extracts using various in vitro assay systems and reported that the watercress extract contain the phenolic and flavonoid contents of $96.2 \mathrm{mg}$ gallic acid equivalents/g dried extract and $63.2 \mathrm{mg}$ catechin equivalents/ $\mathrm{g}$ dried extract, respectively. The extract possessed potent antioxidant properties which mediated through direct trapping of free radicals, reducing power and as well as through metal chelating.

\section{Anti-microbial activity}

Freitas et al., (2013) found synergistic antibacterial activity effects between watercress extract and antibiotics, indicating the potential of watercress compounds as antimicrobial substances.

Table.1 Vitamins and phytochemicals

\begin{tabular}{|c|}
\hline Phytochemicals \\
\hline Calories (kcal) \\
\hline Protein $(\mathbf{g})$ \\
\hline Fat $(\mathbf{g})$ \\
\hline Fibre $(\mathbf{g})$ \\
\hline Beta carotene $(\mathbf{m c g})$ \\
\hline Vitamin A equivalent $(\mathbf{m c g})$ \\
\hline Vitamin B1 $(\mathbf{m g})$ \\
\hline Vitamin B6 (mg) \\
\hline Vitamin $\mathbf{C}(\mathbf{m g})$ \\
\hline Vitamin $\mathbf{E}(\mathbf{m g})$ \\
\hline Folate $(\mathbf{m c g})$ \\
\hline Vitamin $\mathbf{K}(\mathbf{m c g})$ \\
\hline
\end{tabular}

\begin{tabular}{|c|}
\hline Quantity/80 g edible produce \\
\hline 18 \\
\hline 2.4 \\
\hline 0.8 \\
\hline 1.2 \\
\hline 2016 \\
336 \\
0.13 \\
0.18 \\
50 \\
\hline 1.17 \\
\hline 36 \\
\hline 200 \\
\hline
\end{tabular}

Table.2 Mineral composition of raw watercress (FSA, 2002); Pradhan et al., (2015)

\begin{tabular}{|c|}
\hline Mineral composition \\
Calcium (mg) \\
\hline Iodine (mcg) \\
\hline Iron $(\mathbf{m g})$ \\
\hline Magnesium $(\mathbf{m g})$ \\
\hline Manganese $(\mathbf{m g})$ \\
\hline Phosphorus $(\mathbf{m g})$ \\
\hline Potassium $(\mathbf{m g})$ \\
\hline Zinc $(\mathbf{m g})$ \\
\hline Selenium $(\mathbf{m c g})$ \\
\hline Sodium $(\mathbf{m g} / 100 g)$ \\
\hline Copper $(\mathbf{m g} / 100$ g) \\
\hline
\end{tabular}

\begin{tabular}{|c|}
\hline Quantity/80g edible produce \\
\hline 136 \\
\hline 12 \\
\hline 1.8 \\
\hline 12 \\
\hline 0.5 \\
\hline 42 \\
\hline 184 \\
\hline 0.6 \\
\hline 1.6 \\
\hline 68.8 \\
\hline 0.58 \\
\hline
\end{tabular}


Table.3 Chemical and common names of glucosinolates present in watercress

\begin{tabular}{|l|c|}
\hline Chemical name & Common name \\
\hline Benral & Glucotropaeolin \\
\hline 4-Hydroxybenzyl & [Gluco]sinalbin \\
\hline 2-Phenylethyl & Gluconasturtiin; phenenthyl \\
\hline 7-(Methylsulfinyl) heptyl & Glucoibarin \\
\hline 8-(Methylsulfinyl)octyl & Glucohirsutin \\
\hline 7-(Methylthio)heptyl & \\
\hline 9-(Methylthio)nonyl & \\
\hline 8-(Methylthio)octyl & \\
\hline
\end{tabular}

The extract of watercress has also shown nematicide effect on northern root-knot nematode (Meloidogynehapla) (Zahradníková and Petríková, 2012). It was proved that the alcoholic extract of watercress was capable of bringing about the desired antifungal effect in a concentration dependent manner (Nikan and Kavari, 2014). Sadeghi (2014) tested the antimicrobial activities of Ag-Nps against the growth of Gram-positive ( $S$. aureus) using SEM and observed inhibition effect in the AgNPs against $S$. aureus and also confirmed that the watercress is a very good eco-friendly and nontoxic source for the synthesis of Ag-NPs.

\section{Medicinal properties}

\section{Anticancer}

In addition to studies of isolated phytochemicals and other vital nutrients, a number of researches have conducted with regards to significant effects of $N$. officinale extracts which predominantly focusing on chemo-preventive capabilities. Boyd et al., (2006) demonstrated that watercress extract protects colon cancer HT29 cells from oxidative DNA damage induce by various genotoxins, 4-Hydrooxy Nonenal, hydrogen peroxide, and faecal water. Hecht et al., (1995) reported that the consumption of watercress, 56. $8 \mathrm{~g}$ for each 3 days inhibited the metabolic activities of a key tobacco carcinogen NNK in some smokers.
Furthermore, consumption of $85 \mathrm{~g}$ of raw watercress once a day for eight weeks decreased several measures of DNA damage in Lymphocytes, a cancer biomarker and increased plasma levels of the antioxidant, $\beta$ carotene and lutin. Rose et al., (2005) demonstrated that watercress extract, although more specifically the non-volatile 7methylsulphinylheptyl isothiocyanate component, reduced MMP9 activity in the human breast cancer MDAMB- 231 cell-line.

\section{Anti-diabetic}

Diabetes is today's concerned among the major health related problem. It is an important disease which leads to serious complications. Engelen et al., (2006) reported that watercress contains a substance glucosinolates named as gluconasturtin, which has been traditionally used for treatment of diabetes, an endocrinal chronic disease which is caused by altered carbohydrate metabolism and characterized by elevated blood glucose levels.

While studying the effect of $N$. officinale on blood glucose level in diabetic rats Hoseini et al., (2009) observed decreasing of blood glucose was comparable with glycenclamide as an anti-diabetic drug and conclude that $N$. officinaleis a potential source of anti hyperglycemic and possess pharmacologically active component(s). 
Anti-tuberculosis, cardio protective and hepatoprotective

Corona et al., (2008) reported N. officinaleas most potent $(\mathrm{MIC} \leq 100 \mu \mathrm{g} / \mathrm{ml})$ against the four mono-resistant variants tested against tuberculosis. Alcoholic extract of $N$. officinale plant at the dose of $40 \mathrm{mg} / \mathrm{kg}$ can significantly diminish liver damage of acetaminophen in the in-situ rat liver model as studied by Natanzi et al., (2009). N. officinale may play a protective role against acetaminopheninduced hepatotoxicity through maintaining the normal liver functions Natanzi et al., (2010).

It can be concluded from the comprehensive literature, $N$. officinale is a vital source of medicine and economically important herb. They are widely and very popularly used as vegetables and salad. Also, their potentialities against certain disease are proved experimentally during past years. The herb shows powerful anticancer activity with biologically active compounds like gluconasturtine. More than the anticancer it also possess anti-diabetic, anti-tuberculosis, anti-inflammatory, antimicrobial, cardioprotective, etc. thus we can suggest that $N$. officinale can be viewed and used as a source of nutraceuticals and nutrient supplements.

\section{References}

Abu- Zinadah, O., 2008. Effect of watercress oil on the thermal and chemical burn injuries in rabbits. JKAU, Medical Sciences. 15(4): 3-17.

Aires, A., Carvalho, R., Rosa, E. A. S. and Saavedra, M. J. 2013. Phytochemical characterization and antioxidant properties of baby- leaf watercress produced under organic production system. CyTA- Journal of Food. 11(4): 343-351.
Alam, Z., 2015. Phenolic profile and antioxidant potential of wild watercress (N. officinale L.). Zeb Springer Plus. 4:714.

Bahramikia, S. and Yazdanparast, R. 2010. Antioxidant efficacy of Nasturtium officinale extracts using various in vitro assay systems. Journal of Acupuncture and Meridian Studies. 3:283-90.

Bahramikia, S., Ardestani, A. and Yazdanparast, R. 2009. Protective effects of four Iranian, medicinal plants against free radical-mediated protein oxidation. Food Chemestry. 1159(1): 37-42.

Boyd, L. A., McCann, M. J., Hashim, Y., Bennett, R. N., Gill, C. I. and Rowland, I. R. 2006. Assessment of the antigenotoxic, anti-proliferative, and antimetastatic potential of crude watercress extract in human colon cancer cells. Nutrition and Cancer.55: 232-241.

Callaway, E.C., Zhang, Y., Chew, W. and Chow, H. H. S. 2004. Cellular accumulation of dietary anticarcinogenic isothiocyanates is followed by transporter-mediated export as dithiocarbamates. Cancer Letters. 204: 23-31.

Corona, M. D. R. C., Monica, A., Cabrera, R., Santigo, O. G., González,E. G., Palacios, I. D. P. and Herrera, J. L. 2008. Activity against Drug ResistantTuberculosis Strains of Plants used in Mexican Traditional Medicine to treat Tuberculosis and Other Respiratory Diseases. Phytotherapeutic Research.22: $82-85$.

Engelen, E. G., Holden, G., Cohen, J. D. and Gardner, G. 2006. The effect of temperature, photoperiod, and light quality on gluconasturtiin concentration in watercress (Nasturtium officinale R. Br.). Journal of Agriculture and Food Chemestry. 54: 328-334. 
Fahey, J. W., Zalcmann, A. T. and Talalay, P. 2001. The chemical diversity and distribution of glucosinolates and isothiocyanates among plants. Phytochemistry, 56: 5-51.

Food Standards Agency (2002) McCance \& Widdowson's The Composition of Foods, 6th Summary Edition. Cambridge: Royal Society of Chemistry.

Freitas, E., Aires, A., de Santos, R. E. A. and Saavedra, M. J. 2013. Antibacterial activity and synergistic effect between watercress extracts, 2-phenylethyl isothiocyanate and antibiotics against 11 isolates of Escherichia coli from clinical and animal source. Letters in Applied Microbiolgy. 57(4): 266-73.

Graf, B. L., Silva, P. R. and Baldeon, M. E. 2016. Discovering the Pharmacological Potential of Ecuadorian Market Plants using a Screens-to-Nature Participatory Approach. Journal of Biodiversity, Bioprospecting and Developement. 3(1): 1-9.

Guarrera, P. M, Salerna, G., Caneva, G. 2005. Folk phytotherapeutical plans from Marateaarea (Basilicata, Italy). Journal of Ethnopharmacology. 99(3):367-378.

Hecht, S., Chung, F., Richie, J., Akerkar, S., Borukhova, A., Skowronski, L. and Carmella, S. 1995. Effects of watercress consumption on metabolism of a tobacco specific lung carcinogen in smokers. Cancer Epidemiology Biomarkers and Prevention.4: 877 884.

Hedges, L. J. \&Lister. C. E. 2005. Nutritional attributes of salad vegetables. Crop \& Food Research Confidential Report No.1473, New Zealand Institute for Crop \& Food Research Limited.

Hoseini, H. F., Gohari, A. R., Saeidnia, S., Majd, N. S. and Hadjiakhoondi, A.2009. The effect of $N$. officinale on blood glucose level in diabetic rats. Pharmacologyonline, 3: 866-871.

Kumari, S., Sharma, S. and Dutt, B. 2015. Traditional uses of common herbs of Baijnathregion of Himachal Pradesh, India. World Journal of Pharmecy and Pharmaceutical Science. 4(10): 916922.

Matsushima, K., Nemoto, K., Nakashima, N., Dema, D., Thapa, L., Watanabe, A., Maegawa, F., Baba, T. and Matsushita, G. 2006. Report of investigation for wild edible plants and their traditional knowledge in Bhutan. Journal of Faculty of Agriculture Shinshu University. 42(1/2):37-46.

Natanzi, A. R. E., M. H., Monsef Esfehani, H. R., Menaei, M. B., Nazarian, H. and Sabzevari, O. 2010. Antihepatotoxic effect of watercress extract and its fractions in leaves. International Journal of Pharmacology. 6(6):896-992.

Natanzi, A.R.E., Ghahremani, M. H., Monsef Esfehani, H. R., Menaei, M. B., Nazarian, H. and Sabzevari, O. 2009. An experimental model for study of the hepatoprotective activity of Nasturtium officinale (Watercress) against acetaminophen toxicity using in situ rat liver system. European Journal of Scientific Research. 38(4): 556-564.

Nikan, J. and Khavari, H. 2014. In vitro antifungal activity of watercress $(N$. officinale) extract against Fusarium solani, the causal agent of potato dry rot. Journal of Herbal Drugs. 5(1): 1924.

Ozen, T., 2009. 'Investigation of antioxidant properties of $N$. officinale (watercress) leaf extracts', Acta Poloniae Pharmaceutica Drug Res. 66 (2): 187193.

Palaniswamy, Usha R., Richard, J., McAvoy, Bernard B. Bible, James D. Stuart. 2003. Ontogenic variations of ascrobic acid and phenathyl isothiocyanate 
concentration in watercress (Nasturtium officinale R.Br.) leaves. Journal of Agriculture and Food Chemestry. 51(18), 5504-5509.

Pradhan, S., S. Manivannan, and J. P. Tamang. 2015. Proximate, mineral composition and anti-oxidant properties of some wild leafy vegetables. Journal of Scientific and Industrial Research. 74: $155-159$.

Rose, P., Q. Huang, C.N. Ong, and M. Whiteman. 2005. Broccoli and Watercress suppress matrix metalloproteinase- 9 activity and invasiveness of human MDA- MB-2 31 breast cancer cells. Toxicology and applied pharmacology. 209: 105-113.

Sadeghi, B., 2014. Synthesis of silver nanoparticles using leaves aqueous extract of Nasturtium officinale and its antibacterial activity. International
Journal of Molecular and Clinical Microbiology. 2:428-434.

Shahrokhi, N., M. K. Hadad, Z. Keshavarzi, and M. Shabani. 2009. Effect of aqueous extract of watercress on glucose and lipid plasma in streptozotocin induced diabetic rats. Pakistan Journal of Physiology. 5(2): 610.

Yazdanparast, R., S. Bahramikia, and A. Ardestani. 2008. Nasturtium officinale reduces oxidative stress and enhances antioxidant capacity in hypercholesterolaemic rats. ChemicoBiological Interaction. 172: 176-84.

Zahradníková, H. and K. Petríková. 2012. Nematocide effects of watercress (Nasturtium officinale R. BR.) Acta Universitatis Silviculturae Agriculturaeet Mendelianae

\section{How to cite this article:}

Yamuna Pandey, Siddharth S. Bhatt and Nadia Debbarma. 2018. Watercress (Nasturtium officinale): A Potential Source of Nutraceuticals. Int.J.Curr.Microbiol.App.Sci. 7(02): 26852691. doi: https://doi.org/10.20546/ijcmas.2018.702.325 